\title{
Improvement of Regional Economic Management Mechanisms in the Conditions of Digitization: Foreign and Domestic Experience
}

\author{
Pyankova S.G. \\ Ural State University of Economics, 8 Marta/ Narodnoy Voli, 66/45, Ekaterinburg 620114, Russia \\ Corresponding author.Email: silen_06@list.ru
}

\begin{abstract}
In the article, the author presents the proposals of Russian and foreign scientists and researchers regarding the improvement of mechanisms for managing the regional economies in the context of digitalization. The characteristic of the concepts "digital economy", "management", "mechanism of managing the regional economy" is presented. The scientists' proposals on the research methodology of the issue under consideration are summarized. A spectrum of mechanisms is proposed to increase the efficiency of managing the region's economy in the context of digitalization (developing strategic programs to improve the efficiency of information systems in the region, creating development institutions to improve the processes of managing the region's economy in digitalization, developing information systems for automated calculation budget spending efficiency; identification and analysis of "failures" of the development of digital systems in the regions, and others). These mechanisms will improve the efficiency of managing the economy of the region, improve the efficiency of spending budget funds, improve the skills of state authorities, and develop a digitalization system in the region.
\end{abstract}

Keywords: digitalization, regional economy management, information systems, innovative mechanisms

\section{INTRODUCTION}

Currently, the development of the digitalization process is promoting the introduction of new and improvement of existing mechanisms for managing the economy of each region, which subsequently leads to more effective results of their socio-economic development.

In the monograph by Mitrofanova I.V., Ryabova I.A., Fetisova O.V., Pyankova S.G., Shcherbinina A.B. [1] it is stated: "...digitalization is transforming the economy and society by changing the way people interact, the functioning and innovation of enterprises, and the development and implementation of policies by governments."

The term "digital economy" was introduced by the Canadian scientist D. Tapscott: "it is an economy based on digital technology" [2].

Digital innovation has started to spread in the world since the 1960s. Two stages of their development are noted in science: the first is the automation of existing technologies and business processes (since the 1960s); the second is the global penetration of the Internet and mobile communications into social life (since the mid-1990s) [1]. In the Decree of the President of the Russian Federation dated 09.05.2017 No. 203 "On the Strategy for the Development of the Information Society of the Russian Federation for 2017-2030." the following interpretation of this concept is given: "Digital economy is an economic activity in which the key factor of production is digital data. Compared with traditional forms of management, the processing of large volumes of data and the use of analysis results can significantly increase the efficiency of various types of production, technologies, storage, sales, delivery of goods and services."

Scientists and researchers provide the following definitions of the concept of "digital economy":

"This is an automated management of economy based on advanced information technologies; a new economic structure based on the effective management of the production system, which the modern world requires in order to achieve successful economic growth "(DV Evtyanova) [3];

- "this is an economy whose characteristic feature is the maximum satisfaction of the needs of all its participants through the use of information, including personal information" (A. V. Keshelava, V. G. Budanov, V. Yu. Rumyantsev) [4];

- "a set of economic and social activities that are provided by information and communication technologies, such as the Internet, mobile and sensor networks, including the implementation of other types of business based on the use of computers, smartphones and other devices" (L. D. Kapronova) [5]. 
Today, the development of the "digital economy" in Russia is carried out in accordance with the program "Digital Economy of the Russian Federation" (approved by order of the Government of the Russian Federation dated July 28, 2017 No. 1632-r).

Researchers indicate that "the digital economy is developing rapidly, its growth is ahead of other industries: with the country's GDP growing by 7\% from 2011 to 2015 , the volume of the digital economy increased by $59 \%$ over the same period" [6].

According to the "Runet Economy" study conducted by RAEC: "the contribution of the digital economy to the Russian economy in 2018 amounted to $5.1 \%$ of GDP, its average growth is $10-15 \%$ per year" [7].

Okhrimenko I., Sovik I., Pyankova S. and Lukyanova A. present the trends of digital transformation of the socioeconomic system, the prospect of digitalization in society [8].

In the Modern Economic Dictionary, the concept of "management" is defined as "deliberate targeted action on the part of entities, governing bodies on people and economic objects, carried out with the aim of directing their actions and obtaining the desired results" [9]. The classical theory of management defines "management" as a process of planning, organization, motivation and control [10].

Theoretical approaches to managing the economy of the region are presented in a fairly wide range of works of Russian and foreign researchers. We can distinguish the works of the following authors: Animitsa EG, Sukhikh VA, Novikova NV [11], Buresh OV, Iskhakova AF [12], Mashunin Yu.K. [13], Grishin V.Yu. [14], Samofalova E.V. [15], Lobor A.V. [16], Marshalova A.S., Novoselov A.S. [17] and others.

The author believes that the most expanded description of the conceptual apparatus regarding the phrase "regional economy management mechanism" is presented in the work of I. Lyapina, where it is "a key element of the territorial management system, its most complex part, which is a combination of components (governing bodies, their functions and structures; targeted strategic objectives; principles, methods, technologies and management tools, etc.) " [18].

Many scientists have developed a grouping of mechanisms for managing the region's economy. In particular, Krivonosov K.K. divides these mechanisms into three blocks: "legislative regulation, financial and budgetary regulation of the economy, tax regulation of the economy" [19].

The issues of digitalization of the regional economy are discussed in works by Gasheva ZD [20], Zemtsov S., Barinova V., Semenova R. [21], Ivanova EV, Efremkova TI, Shipunova V .V., Sabanova L.N. [22].

The progressive development of the digitalization process has stimulated the introduction of new and improved mechanisms for managing the economy of the territories, namely: the opening and development of regional development institutions [23]; the introduction of government support measures aimed at developing a business actively introducing digital technologies [24]; creation of legal regulation for digital innovations [25]; inclusion of measures for the development of digitalization processes in strategic planning documents for regions; introduction of online broadcasts of meetings between different territories; opening and development of multifunctional consulting centres; operational services in public sector institutions; use of project management; implementation of an operational information system for monitoring the implementation of indicators of socioeconomic development of territories; and others.

The implementation of the above mechanisms resulted in increased competitiveness of the regions [26,27], changes in the dynamics of development and the appearance of entire industries.

\section{RESEARCH METHODOLOGY}

Currently, there is a number of methodologies, techniques and models aimed at improving the process of managing the economy of the region. In particular:

- Rumyantsev S.S. defined "Methodological recommendations on increasing the efficiency of the functioning of the mechanism for managing the economy of the regions at the municipal level based on an integrated approach to structuring and rationalizing the individual stages of the management process" [28]

- Lyapina I.R. developed "A methodology has been developed for a qualitative assessment of the effectiveness of managing the region's economy" [18];

- Neverov A.V. and Masilevich N.A. developed "a model for sustainable development of the region based on the construction of an integral indicator of the development of the green economy, the functioning of which is aimed at increasing regional capital and balanced, interdependent reproduction of its main elements - human, economic and environmental capital" [29];

- Tolstoguzov O.V. proposed "a holistic concept of managing the economy of the peripheral border region in the context of the active involvement of regional resources in the global economy, created on the basis of the structural relationships of the model of center-peripheral interactions, taking into account the features and role of the border regions in the context of globalization and the requirements to achieve the conditions for the innovative development of the region" [30];

- Safronov V.A. compiled methods for predicting the dynamics of general economic indicators of the development of the region at the macro level using elements of instrumental impact; a threesector financial macro-model of the region's economy was proposed, which allows one to characterize the relationships between different 
sectors of the region's economy and describe these relationships by economic categories [31];

- Krotova M.A. developed a "cognitive model of managing the region's economy (5 blocks), which allows removing horizontal barriers to management and interaction between central and peripheral zones based on coordination of managerial functions of federal, regional and municipal authorities in terms of exercising their powers to form the prerequisites for the growth of multi-level competitiveness of individual territories" [32];

- Gribanov Yu.I. presented "a methodological approach to the formation and development of digital platforms, considered as a set of integrated tools based on modern digital technologies, the use of which increases the efficiency of management in the socio-economic system, characterized by the positioning of digital platforms as technological integrators of a set of services related to the digital economy" [33].

The author has consolidated the proposals of scientists and researchers on introducing new and improving mechanisms for managing the economy of the regions in the context of digitalization:

- introduction of new principles for the provision of public services such as electronic form, proactivity (provision of services prior to the actual appeal of the applicant) and extraterritoriality (Ministry of Economic Development of the Russian Federation) [34];

- adjustment of strategic planning documents taking into account the inclusion of measures to develop the digitalization system. The proposal is described in the abstract of the author's dissertation "Theory and methodology of systemic socio-economic development of monospecialized territories based on institutional renewal" (Pyankova SG) [35];

- implementation of state support for producers through stabilization institutions and development institutions. The proposal was presented by the author on the map of the territorial institutional system in the article "Theoretical Foundations of the Development of the Municipal Economy and Local SelfGovernment" (Pyankova SG) [36];

- organization of coordinated actions by federal bodies of state power, bodies of state power of constituent entities of the federation, local authorities to create the most favorable conditions for the development of the economy of constituent entities of the federation; use of two types of planning: medium-term and operational (Buresh OV, Iskhakova AF) [37];

- introduction of information systems for planning the socio-economic development of regions;
- the creation of stabilization and development nodes, which are widespread in many developed countries, and suggesting that in less developed areas there should be specially allocated territories on which new territorial-production entities will be formed by joint efforts of the state, regional and local authorities, the private sector and foreign investors (Kail Ya.Ya., Epinina V.S.) [38];

- development of a system of program-targeted management of the economy (Shurdumova EG, Kazieva BV, Nagoyev A.B.) [39];

- development of an information-digital system for ensuring the unity of the educational and personnel policy of the region (Grigoryev S.G., Lukin V.V., Lukin D.V.) [40].

Golitsyn N.S., Gulyaev Yu.V., Kurkovsky A.P., Makhutov N.A., Frolov K.V. proposed "a sequence of actions, the implementation of which will create a methodological and informational basis for determining possible strategies for the transition of territories to sustainable development." One of the key actions proposed is "to conduct computational experiments on simulation models to obtain quantitative characteristics of alternative options for regional development strategies of the region, scenarios and strategies for sustainable development" [41].

Researchers at the Department of Regional and Municipal Management of the IEIE SB RAS note that "improving the efficiency and quality of strategic management of the territory is directly related to the involvement of innovative tools and information technologies that are adequate to modern tasks and the pace of their implementation" [42]. This requirement is met by the system-balance-optimization model developed by them, which allows the administration of the territory to regularly monitor socio-economic development, as well as develop economically feasible plans to achieve the target level of indicators for several years ahead [43].

In foreign territories, various public organizations are created for joint coordinated actions of government and business in the direction of socioeconomic development, such as the Marketing Huddersfield Partnership (an alliance of state, private, nonprofit organizations in Huddersfield, UK), the IBA Territory Development Agency (Emsher Park, Germany) [44].

A number of innovative mechanisms for managing the economy of the regions in the context of digitalization are also being implemented abroad, in particular:

- In Europe, marketplaces are created. These are special aggregate platforms where customers can choose different suppliers of goods and services. For example, Raisin is a European market place for bank deposits. It makes it possible to open a deposit in any EU bank. According to 2017 data, more than 75,000 customers used the platform [45]. 
- In Germany, there are such programs as the development of convergent information and communication technologies aimed at promoting small and medium-sized companies; competition of individuals - founders of companies in the field of information and communication technologies for starting capital [46].

- A system of "digital city management" has been introduced in Beijing. "Digital city management" is the placement of city management activities on a computer network platform, the digitization of city information. Today, thanks to the implementation of this system, the level of active detection of municipal problems reaches more than $90 \%$ [47].

\section{RESEARCH RESULTS, DISCUSSION OF THE RESULTS}

Given the results of the study, the author proposes the following mechanisms to improve the efficiency of managing the economy of the region in the context of digitalization:

- development of strategic programs to improve the efficiency of information systems in the region;

- creation of development institutions to improve the processes of managing the economy of the region in the context of digitalization;

- development of information systems for the automated calculation of the efficiency of spending budget funds;

- identification and analysis of "failures" in the development of digital systems in the regions;

- holding a competition among the regions on the implementation of best practices of improving the efficiency of managing the region's economy in the context of digitalization;

- the introduction of a system of grants to regions that have achieved the best results in the development of the digitalization process;

\section{REFERENCES}

[1] Mitrofanova I.V., Digitalization of the economy: world, Russia, regions: monograph / I.V. Mitrofanova [et al.]. M.: Berlin: Direct Media, 2019.

[2] Tapscott, D., Blockchain Revolution: HowtheTechnologyBehindBitcoinIs ChangingMoney, Business, and the World / D. Tapscott, A. Tapscott. London: Penguin, 2016.348 p.

[3] Evtyanova, D.V., Criteria for creating digital economic management platforms / D.V. Evtyanova.
- conducting training for government officials on improvement of the digitalization process in the region;

- development of program-targeted approaches in the process of managing the economy of the region [48];

- development of methodological manuals on improving mechanisms for managing the economy of the region.

These mechanisms will improve the efficiency of managing the economy of the region as well as the efficiency of spending budget funds, improve the skills of state authorities, and develop a digitalization system in the region.

flexible transformation, segmentation of the tourism and hotel markets for better services [12].

Foreign scientists in their works make the main emphasis on information technologies inherent in the digital economy. Knowledge and skills acquired by students of higher and secondary educational institutions in both full-time and part-time forms of education should be immensely transformed into mastering the achievements of the digital economy. Booking tours and consulting regular customers in tourism require competence in modern information technologies.

\section{CONCLUSION}

Thus, at present, the question of improving mechanisms for managing the economies of the regions in the context of expanding digitalization processes is extremely important both in Russia and abroad. The result of the introduction of these mechanisms is a more progressive growth of the socio-economic development of territories, an increase in the efficiency of public administration, an increase in the efficiency of the provision of services to the population, and an increase in public satisfaction with the city administration.

Economic systems. T. 10, No. 3 (38). M .: Publishing and trading corporation "Dashkov and K", 2017.

[4] Keshelava A.V., Introduction to the Digital Economy / A. V. Keshelava, V. G. Budanov, V. Yu. Rumyantsev and others; under the general. ed. A.V. Keshelava. M .: VNIIGeosystem, 2017.28 p.

[5] Kapranova L. D., Digital economy in Russia: state and development prospects / L.D. Kapranova // Economics. Taxes. Right. No. 2. FSBEI HE "Financial University under the Government of the Russian Federation”, 2018. 
http://ekonomika.snauka.ru/2016/11/12952 (12/07/2019).

[17] Marshalova A.S., Novoselov A.S., Methodological problems of the formation of a new regional management system. Region: economics and sociology. No. 1. Novosibirsk: IEOPP SB RAS, 2012. S. 40-53. [18] Lyapina I.R.,Modernization of the mechanism for managing the economy of the region in the context of strengthening the independence of the territories: author. dis. ... doc. econ. Sciences: 08.00.05 / Lyapina Innara Rafailievna. Tambov: Tambov State University named after G.R. Derzhavina, 2012.46 p.

[19] Krivonos K.K., Mechanisms for managing the economy of the Rostov region: analytical aspect. Economics, Statistics and Informatics. No. 5. M : MESI, 2013. S. 56-58.

[20] Gasheva Z.D., Digitalization of the regional economy: concepts, problems, ways of implementation. New Technologies, 2018. [Electronic resource]. URL: https://cyberleninka.ru/article/n/tsifrovizatsiyaregionalnoy-ekonomiki-ponyatiya-problemy-putirealizatsii (10.12.2019).

[21] Zemtsov S., Barinova V., Semenova R., Risks of digitalization and adaptation of labor markets in Russia. Foresight. T.13. No. 2.SPB., 2019.

[22] Ivanova E.V., Efremkova T.I., Shipunova V.V., Sabanova L.N., Problems and prospects of digitalization of the economy of the Kemerovo region. Regional Economics and Management: An Electronic Scientific Journal. No. 1, 2019. [Electronic resource]. URL: https://eee-region.ru/article/5706/ (December 10, 2019).

[23] Pyankova S., Ergunova O., The role of regional development institutions in the social and economic development // 5th International Multidisciplinary Scientific Conference on Social Sciences and Arts SGEM 2018, www.sgemsocial.org, SGEM2018 Conference Proceedings, ISBN 978-619 -7408-63-8/ ISSN 2367-5659, 26 August - 1 September, 2018, Vol. 5, Issue 1.3, 885-892 pp.

[24] Andreeva I.L., Golovina T.A., Polyanin A.V. State regulation of priority areas of entrepreneurship in the digital economy. State and municipal government. SKAGS Accounts. 2018. [Electronic resource]. URL: https://cyberleninka.ru/article/n/gosudarstvennoeregulirovanie-prioritetnyh-napravleniypredprinimatelstva-v-usloviyah-tsifrovoy-ekonomiki/ viewer(December 10, 2019). 
[34] The new principle of public services - electronic

[25] Digitalization of social services - interest is growing. Finmarket. September 17, 2018. [Electronic resource].

URL:

http://www.finmarket.ru/main/article/4851113

(December 10, 2019).

[26] Grebenkina E.N., Regional competitiveness management: strategic directions and tools: Diss. ... cand. econ. Sciences: 08.00.05 / Grebenkina Elena Nikolaevna. Kursk: FSBEI HPE Voronezh State University, 2014. $224 \mathrm{p}$.

[27] Savelyev Yu.V., Regional competitiveness management: from theory to practice / Yu.V. Savelyev; Institute of Economics, KarRC RAS. Petrozavodsk: Karelian Scientific Center of the Russian Academy of Sciences, $2010.516 \mathrm{p}$.

[28] Rumyantsev S.S., Improving the mechanism of managing the economy of the regions at the municipal level: Diss. Candidate of Economic Sciences 08.00.05 / Rumyantsev Stanislav Sergeevich. SPb .: FGOU VPO "St. Petersburg State University of Cinema and Television", 2005. 175 p.

[29] Neverov A.V., Masilevich N.A.. The concept and strategy of sustainable development of the Bialowieza ecological region. Environmental economics. M .: VINITI RAS. S. 69 - 74. [Electronic resource]. URL: https://cyberleninka.ru/article/n/kontseptsiya-istrategiya-ustoychivogo-razvitiya-belovezhskogoekologicheskogo-regiona(December 10, 2019).

[30] Tolstoguzov O.V., The methodology of managing the economy of the border region in the context of globalization: Diss. ... Doct. econ. Sciences 08.00.05 / Tolstoguzov Oleg Viktorovich. St. Petersburg: Institute of Economics, Karelian Scientific Center of the Russian Academy of Sciences, $2011.364 \mathrm{p}$.

[31] Safronov V.A., Economic methods of managing the region: author. Diss ... cand. econ. Sciences 08.00.05 / Safronov Vladimir Alekseevich. M., 1992

[32] Krotova M.A., Improving management methods of the regional economy based on the optimization of spatial and economic transformation: author. diss. Cand. econ. sciences / Krotova Marina Aleksandrovna. Barnaul: NIGHT OF HPE "Institute of Economics, Law and Humanities", 2014.

[33] Gribanov Yu.I., Digital transformation of socioeconomic systems based on the development of the institution of service integration: diss ... doct. econ. sciences. 08.00.05 / Gribanov Yuri Ivanovich. SPb .: St. Petersburg State University of Economics, 2019 form, proactivity and extraterritoriality. The official website of the Ministry of Economic Development of the Russian Federation. 11/25/2019. [Electronic resource]. URL: http://old.economy.gov.ru/minec/about/structure/depgos gv/2019112505 (December 10, 2019).

[35] Pyankova S.G., Theory and methodology of systemic socio-economic development of singleindustry territories based on institutional renewal: author. diss ... doctorate. econ. Sciences / Pyankova Svetlana Grigorevna. Yekaterinburg: Institute of Economics, Ural Branch of the Russian Academy of Sciences, 2015.

[36] Pyankova S.G., The theoretical basis for improving the institutional system of a single-industry territory. Municipality: economics and management. Yekaterinburg: Federal State Budgetary Educational Establishment of Higher Education "Russian Academy of National Economy and Public Administration under the President of the Russian Federation", 2015. No. 3 (12).

[37] Buresh O.V., Iskhakova A.F., State management of the region's economy. Russian business. No. 24. 2012. [Electronic resource]. URL: https://creativeconomy.ru/lib/7865 (accessed December 10, 2019).

[38] Kail Ya.Ya., Epinina V.S., New approaches to managing the development of a region in modern Russia // Actual problems and trends in the development of finance, economics and management: a regional aspect (materials of an interregional scientific and practical conference). Elista: AU RK "Publishing House" Gerel "', 2012. P. 41-48.

[39] Shurdumova E.G., Kazieva B.V., Nagoev A.B., Strategic methods of managing the economy of the region // Fundamental research. No. 2-1. M., 2015.

[40] Grigoriev S.G., Lukin V.V., Lukin D.V. The development of human capital in the context of digitalization. E-Management. No. 2. M $\therefore$ S State Institute of Management, 2018.

[41] Golitsyn N.S., Gulyaev Yu.V., Kurkovsky A.P., Makhutov N.A., Frolov K.V., Methodological and informational basis for assessing the current state of the regions and systemic approaches to determining possible strategies for the transition to sustainable development. [Electronic resource]. URL: http: //www.prometeus.nsc.ru/ (05/27/2015). 
[42] Lipin A.S., Gaiduk E.A., The development model of the municipality // strategic management of the spatial development of the constituent entities of the Federation and cities of Siberia: Sat. scientific tr / Ed. A.S. Novoselova. Novosibirsk: IEOPP SB RAS, 2009.

[43] Gaiduk E.A., Improving the quality of strategic management of a municipality [Electronic resource] // Bulletin of NSU. Series: Socio-economic sciences. 2011. Volume 11, Issue 2. P. 129 - 138. [Electronic resource]. URL: URL: http://www.nsu.ru/exp/ref/Media:23e2684ec85a134fbe 03000014.pdf (05/28/2019).

[44] Century Technologies Promisesand Perilsofa Dynamic Future. [Electronic resource]. URL: http://www.oecd.org/dataoecd/41/16/35391210.pdf $(05 / 27 / 2019)$.

[45] Marketplaces for banks: first steps. Invest Foresight: Best Investment and Financial Cases / Ed. A.S. Genkina, S.S. Nikulina, K.G. Frumkinna. M .: Publishing Solutions, 2017.

[46] Development institutions for state support of innovation: German experience. Ministry of Economic Development of the Russian Federation. FZ-Jülich MGS. [Electronic resource]. URL: http://www.ved.gov.ru/ (05/25/2019).

[47] 戴 轶王昌兰经济快速发展下数字化城市管 理 的 思考. [Electronic resource]. URL: https:/www.ixueshu.com/document/0a6d2bb5681e0c3 b318947a18e7f9386.html.(03/25/2020).

[48] Chebotareva G.S., Strielkowski W., Blaginin V.A. (2019). The renewable energy market: Companies' development and profitability. Upravlenets - The Manager, vol. 10, no. 3, pp. 58-69. DOI: 10.29141/2218-5003-2019-10-3-6. 